\title{
Reactive nitrogen in the environment and its effect on climate change
}

\author{
Jan Willem Erisman ${ }^{1,2}$ \\ Jim Galloway ${ }^{3}$ \\ Sybil Seitzinger ${ }^{4}$ \\ Albert Bleeker ${ }^{1}$ \\ Klaus Butterbach-Bahl ${ }^{5}$
}

\footnotetext{
${ }_{1}$ Energy research Center of the Netherlands, ECN, P.O. Box 1, 1755ZG Petten, the Netherlands

2VU University Amsterdam, Boelelaan 1105, 1081AV Amsterdam, the Netherlands

3 University of Virginia, P.O. Box 400772, Charlottesville, VA, USA 4 International Geosphere-Biosphere Programme (IGBP) Secretariat,

Royal Swedish Academy of Sciences, Box 50005, SE-104 05 Stockholm, Sweden

5 Institute for Meteorology and Climate Research, Atmospheric Environmental Research (IMK-IFU), Karlsruhe Institute of Technology (KIT), Kreuzeckbahnstr. 19, 82467 Garmisch-Partenkirchen, Germany
} 


\section{Reactive nitrogen in the environment and its effect on climate change

\author{
Jan Willem Erisman ${ }^{1,2}$, Jim Galloway ${ }^{3}$, Sybil Seitzinger ${ }^{4}$, Albert Bleeker ${ }^{1}$ \\ and Klaus Butterbach-Bahl ${ }^{5}$
}

\begin{abstract}
Humans have doubled levels of reactive nitrogen in circulation, largely as a result of fertilizer application and fossil fuel burning. This massive alteration of the nitrogen cycle affects climate, food security, energy security, human health and ecosystem services. Our estimates show that nitrogen currently leads to a net-cooling effect on climate with very high uncertainty. The many complex warming and cooling interactions between nitrogen and climate need to be better assessed, taking also into account the other effects of nitrogen on human health, environment and ecosystem services. Through improved nitrogen management substantial reductions in atmospheric greenhouse gas concentrations could be generated, also allowing for other co-benefits, including improving human health and improved provision of ecosystem services, for example clean air and water, and biodiversity.
\end{abstract}

\footnotetext{
Addresses

${ }^{1}$ Energy research Center of the Netherlands, ECN, P.O. Box 1, 1755ZG Petten, the Netherlands

${ }^{2}$ VU University Amsterdam, Boelelaan 1105, 1081AV Amsterdam, the Netherlands

${ }^{3}$ University of Virginia, P.O. Box 400772, Charlottesville, VA, USA

${ }^{4}$ International Geosphere-Biosphere Programme (IGBP) Secretariat, Royal Swedish Academy of Sciences, Box 50005, SE-104 05 Stockholm, Sweden

${ }^{5}$ Institute for Meteorology and Climate Research, Atmospheric Environmental Research (IMK-IFU), Karlsruhe Institute of Technology (KIT), Kreuzeckbahnstr. 19, 82467 Garmisch-Partenkirchen, Germany
}

Corresponding author: Erisman, Jan Willem (erisman@ecn.nl)

Current Opinion in Environmental Sustainability 2011, 3:281-290
This review comes from a themed issue on
Carbon and nitrogen cycles
Edited by Carolien Kroeze and Lex Bouwman
Received 30 April 2011 ; Accepted 17 August 2011
Available online 8 th September 2011
1877-3435/ $\$$ - see front matter
C 2011 Elsevier B.V. All rights reserved.
DOI $10.1016 /$ j.cosust.2011.08.012

\section{Introduction}

Several drivers, or forcing agents, can affect the Earth's biological, chemical and physical processes at a planetary scale. Humans are now the prime driver of global change, which includes climate change, reduced water quality and availability, biodiversity loss and degraded ecosystem services - the services provided by nature for free for example, fertile soils, clean air, pollination and water purification [e.g. $\left.\left[1-4,5^{\circ}\right]\right]$. These also affect human health.

The human drivers include a growing population and changing per capita consumption patterns both of which affect food, feed, livestock and fiber production, energy (fossil fuel and biofuel) use, land-use changes as well as social equity. Directly or indirectly, these lead to planetary-scale changes to biogeochemical cycles of nitrogen, carbon, phosphorous, sulfur, etc., which result in changes in our biological and ecological systems pushing the earth system to its planetary boundaries or even beyond $\left[5^{\bullet}\right]$. The anthropogenic induced changes of the biogeochemical cycles of carbon, $\mathrm{C}$, as well as of nitrogen, $\mathrm{N}$, have already resulted in changes of the atmospheric composition, with detectable consequences for the climate system. Obviously, due to the close interaction of the biogeochemical cycles human intervention creates many feedbacks such as between increased atmospheric $\mathrm{CO}_{2}$ concentrations and increased plant $\mathrm{C}$ sequestration, which will have direct and indirect consequences for the rate of climate change.

Of increasing importance to these climate feedbacks are the short-lived atmospheric species (e.g. ozone, $\mathrm{O}_{3}$; nitrogen oxides, $\mathrm{NO}_{\mathrm{x}}$; ammonia, $\mathrm{NH}_{3}$; aerosols) [e.g. [6 $\left.6^{\bullet}, 7-9\right]$ ]. Most previous studies have addressed the $\mathrm{O}_{3}$-aerosol impacts, including black carbon, on the radiative balance. While attention is being given to these short-lived species, to date environmental assessments, including the IPCC assessments, have largely ignored the effects of reactive nitrogen $\left(\mathrm{N}_{\mathrm{r}}\right)$ on climate and climate feedbacks, with the exception of nitrous oxide, $\mathrm{N}_{2} \mathrm{O}$. This is understandable since most reactive nitrogen species such as $\mathrm{NO}_{\mathrm{x}}$ and $\mathrm{NH}_{3}$ are short-lived and therewith irrelevant to long-term climate forcings. Furthermore, there have been high uncertainty levels regarding the links between increased reactive nitrogen levels and the carbon cycle. But, knowledge of the role of reactive nitrogen in climate is expanding rapidly.

The element nitrogen is essential for all life forms on Earth. All plants, animals and humans, need $\mathrm{N}$ to live. It is essential for producing protein ( $\mathrm{N}$ is a part of it), carbohydrates (plants need proteins to assemble carbohydrates so protein availability affects growth rate as well as rates of $\mathrm{CO}_{2}$ fixation) and fibers [e.g. $\left.\left[10^{\bullet}, 11,12\right]\right]$. Nature and its biodiversity can only exist because of the availability, even if limited, of $\mathrm{N}_{\mathrm{r}}$ in the system. $\mathrm{N}_{\mathrm{r}}$ is defined as all 
nitrogen compounds except for $\mathrm{N}_{2}$ and includes, for example, $\mathrm{NH}_{3}$, nitrate $\left(\mathrm{NO}_{3}\right), \mathrm{NO}_{\mathrm{x}}, \mathrm{N}_{2} \mathrm{O}$, amines, and organic forms of nitrogen. Naturally available $\mathrm{N}_{\mathrm{r}}$ is produced mainly by lightning, wildfires and biological $\mathrm{N}_{2}$ fixation (BNF). Humankind has developed technology to produce synthetic $\mathrm{N}_{\mathrm{r}}$ fertilizer, which is used to increase crop and thereby also meat production [50]. Food for about half of the current human population can only be produced due to the availability of synthetic fertilizers [11]. Additionally, farmers increasingly introduced leguminous crops in their crop rotations, thereby increasing nitrogen input to agricultural systems via biological nitrogen fixation. Moreover, mankind also creates $\mathrm{N}_{\mathrm{r}}$ accidentally. Fossil-fuel combustion by industry, the transportation sector and the energy sector not only emits gases such as $\mathrm{CO}_{2}$ and sulfur dioxide, but also $\mathrm{NO}_{\mathrm{x}}$.

Once a $\mathrm{N}_{\mathrm{r}}$ molecule has been created, it may remain in the environment for a considerable time. $\mathrm{N}_{\mathrm{r}}$ is highly mobile and over time, one molecule of $\mathrm{N}_{\mathrm{r}}$ can contribute to several environmental effects as it cascades through the environment $\left[13^{\bullet \bullet}\right]$. During the cascade it drives different environmental impacts such as eutrophication and acidification in space and time, some of which affect radiative forcing (e.g. increased C-sequestration by forest ecosystems or $\mathrm{O}_{3}$ formation due to $\mathrm{NO}_{\mathrm{x}}$ emissions) and therefore climate. The endpoint of the cascade is ultimately the emission of $\mathrm{N}_{2}$ or $\mathrm{N}_{2} \mathrm{O}$; the latter contributes to climate change and stratospheric ozone depletion [2,14]. During the cascade $\mathrm{N}_{\mathrm{r}}$ can influence greenhouse gas exchange with the atmosphere, aerosol production, tropospheric $\mathrm{O}_{3}$, or can increase biological productivity, which requires carbon. All of these have climate impacts.

This paper provides a discussion on the status of reactive nitrogen in the environment and its effect on climate change. It first addresses the relationship between $\mathrm{N}_{r}$ production and $\mathrm{CO}_{2}$ emissions, and then discusses why the $\mathrm{N}_{\mathrm{r}}$ cycles are relevant for the on-going climate change debate. Then the climate impacts of $\mathrm{N}_{\mathrm{r}}$ are quantified in terms of its effect on the radiative balance and finally the policy implications of the above are discussed.

\section{Nitrogen creation and $\mathrm{CO}_{2}$ emissions}

In the past 50-100 years, human activities have caused the global anthropogenic rate of $\mathrm{N}_{2}$ fixation to increase so that it is now 1.5-2 times the natural rate of $\mathrm{BNF}$ in terrestrial ecosystems (Figure 1) $\left[13^{\bullet \bullet}, 50\right]$. Globally, the level of terrestrial and agricultural $\mathrm{BNF}$ is reasonably well known, but regionally still large uncertainties exist with regard to natural terrestrial $\mathrm{BNF}$. On land the natural $\mathrm{BNF}$ is estimated to be about $110 \mathrm{Tg}$ [15] while anthropogenic sources add $100-125 \mathrm{Tg} \mathrm{N}\left[10^{\bullet}, 15,50\right]$. Estimates of $\mathrm{N}_{\mathrm{r}}$ inputs to the open ocean suggest a natural oceanic

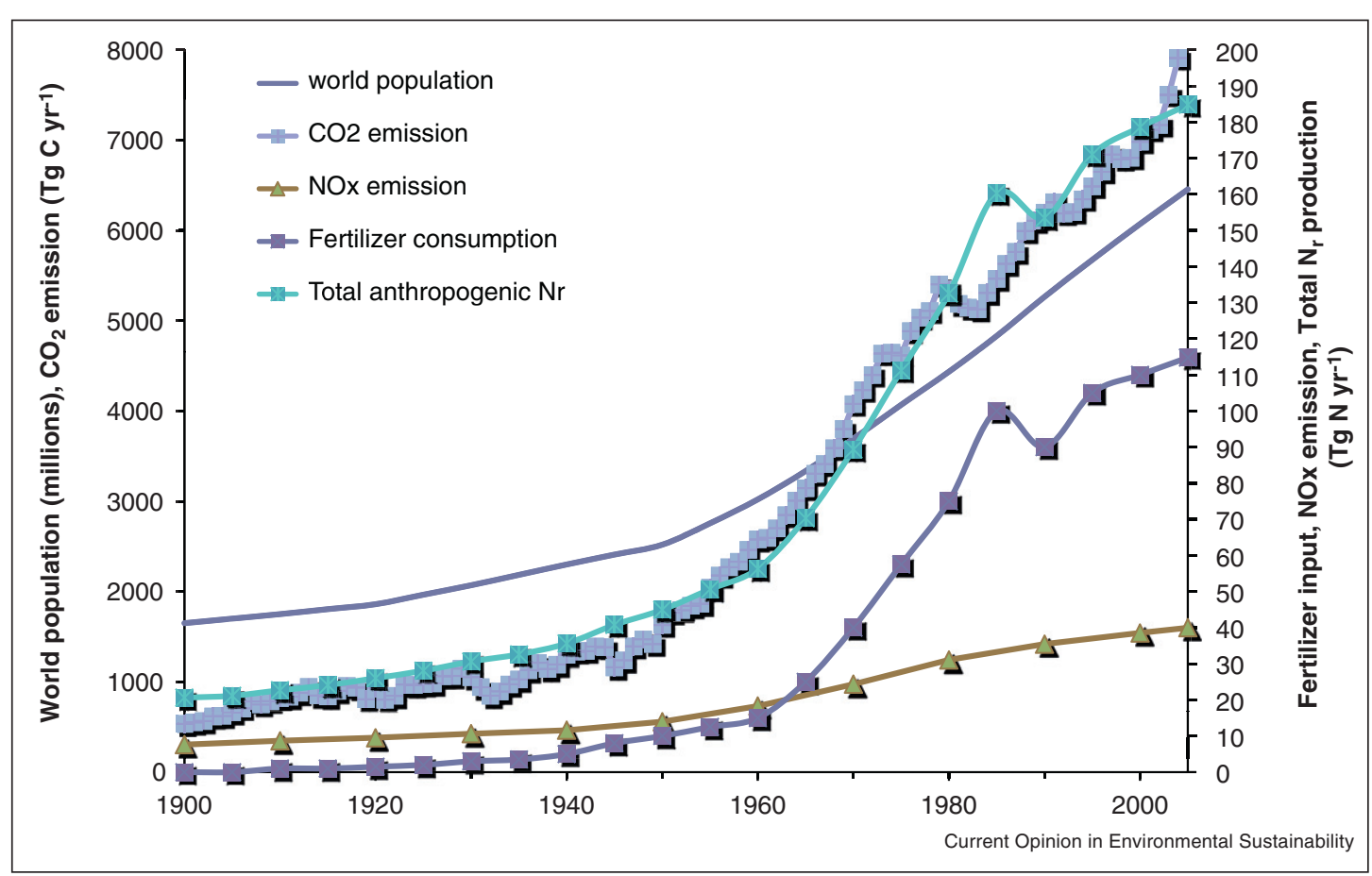

Global trends in human population, $\mathrm{CO}_{2}$ emissions in $\mathrm{Tg} \mathrm{C} \mathrm{[16]} \mathrm{and} \mathrm{total} \mathrm{anthropogenic} \mathrm{reactive} \mathrm{nitrogen} \mathrm{production} \mathrm{(in} \mathrm{Tg} \mathrm{N)} \mathrm{throughout} \mathrm{the} \mathrm{20th}$ century [based on $\left.\left[10^{\circ}, 17\right]\right]$. The graph also includes average fertilizer production and the increase in $\mathrm{NO}_{\mathrm{x}}$ emissions from fossil fuel burning. The natural terrestrial BNF is about $110 \mathrm{Tg} \mathrm{N} \mathrm{yr}^{-1}$ and the natural oceanic BNF is about $140 \mathrm{Tg} \mathrm{N} \mathrm{yr}^{-1}$ [15]. 
BNF rate of approximately $140 \mathrm{Tg} \mathrm{N} \mathrm{yr}^{-1}$, while $90 \mathrm{Tg} \mathrm{N} \mathrm{yr}^{-1}$ are added from various human derived $\mathrm{N}$ sources, such as atmospheric deposition and riverine inputs [15]. The proportion of anthropogenic nitrogen therefore differs between the terrestrial and the marine environment; on land the anthropogenic $\mathrm{N}_{\mathrm{r}}$ input is higher than the natural input, but this is not yet the case in the ocean.

Figure 1 shows the global trends in $\mathrm{N}_{\mathrm{r}}$ production. The graph depicts ammonia production for fertilizer and industry, total $\mathrm{N}_{2}$ fixation, $\mathrm{NO}_{\mathrm{x}}$ emissions from fossil fuel burning, together with global fossil fuel related $\mathrm{CO}_{2}$ emissions and the world population. There is a high correlation between $\mathrm{CO}_{2}$ emissions and $\mathrm{N}_{\mathrm{r}}$ production because of the similarity between the drivers (food, feed and energy) and, to some extent, the sources. This shows the strong correlation between nitrogen enrichment and climate change (through $\mathrm{CO}_{2}$ emissions) at a source level, as nitrogen is the key parameter allowing sustaining a growing world population with its increasing demand for energy from fossil fuels.

Since the 80 s of the last century the human $\mathrm{N}_{\mathrm{r}}$ production exceeds that of the natural terrestrial BNF. Furthermore, since then the graph shows a strong linear correlation between both $\mathrm{CO}_{2}$ and $\mathrm{N}_{\mathrm{r}}$ with the increase in world population. For each increase of the world population with one billion people another approximately $25 \mathrm{Tg} \mathrm{N}$ and $1 \mathrm{Pg} \mathrm{CO}_{2}-\mathrm{C}$ is added annually to the environment, which makes prediction easy if no measures are taken.

\section{The relevance of short-lived $\mathrm{Nr}$ to climate}

A characteristic of climate change is the long atmospheric residence time of non-reactive greenhouse gases (GHG), such as $\mathrm{N}_{2} \mathrm{O}$ and $\mathrm{CO}_{2}$. The climate warming effects of the GHG are expressed in the global warming potential (GWP). $\mathrm{CO}_{2}$ is the reference chemical for determining GWP, so it has a value of $1 . \mathrm{N}_{2} \mathrm{O}$ has a value of 298 (i.e. a 298 times stronger GHG in terms of GWP) and $\mathrm{CH}_{4}$ of 26 over a 100-year time horizon [2]. The change in radiative forcing due to GHG and aerosols is computed based on 'unperturbed' values, defined by the Intergovernmental Panel on Climate Change (IPCC) as the measured difference relative to the year 1750. A positive forcing (more incoming energy stays in the system) tends to warm the earth system, while a negative forcing (more outgoing energy) tends to cool it. Here we assume that the forcing through short-lived constituents can be calculated as done in [2] using their continuous supply over the last 100 years. Current policies will only take effect in the long term because measures to mitigate climate change will not reduce atmospheric concentrations of GHG. At best, concentrations will stabilize over the coming decades. Historical, present day and future anthropogenic changes of the N-cycle and effects on the biosphere-atmosphere exchange of $\mathrm{N}_{\mathrm{r}}$ compounds are characterized mainly as short-lived, that is, shorter atmospheric residence times compared to the lifetime of GHGs, except for $\mathrm{N}_{2} \mathrm{O}$.

Figure 2 shows major areas where nitrogen and climate interact, visualized by the flows in the N-cycle and the greenhouse gas and radiative forcing links. The long-term effects represent the effect on carbon storage in the soil and the effects on greenhouse gas emissions, such as $\mathrm{N}_{2} \mathrm{O}$. $\mathrm{N}_{2} \mathrm{O}$ can be formed and emitted in several places along the $\mathrm{N}$ cascade. As shown in Figure $2, \mathrm{~N}_{\mathrm{r}}$ is involved in numerous processes forming short-lived atmospheric substances having a significant impact on the Earth's radiative balance in the short term. A good example is particulate matter or aerosols and the contribution of nitrogen to aerosol formation processes. A significant share of aerosols is, for example, ammonium sulfate or ammonium nitrate-aerosols, which are affecting the Earth's radiative balance directly (they reflect incoming solar radiation) and indirectly by affecting cloud formation. However, their lifetime in the atmosphere is in the order of hours to weeks [e.g. [2,9,18,19]].

Aerosols and other short-lived pollutants do not have the cumulative and sustained effects on climate that greenhouse gases do. Decreasing aerosol formation, therefore, has a short-term effect on climate and therefore these short-lived species are not considered relevant for the climate-change policies. The same arguments have been used for limited attention to the other changes in the Ncycle. However, there are arguments against this. Firstly, in developed countries it has been proven difficult to reduce nitrogen and other air pollutants from the sources, such as fertilizers, industry and energy. In other parts of the world these sources will increase for several decades until measures are taken. So $\mathrm{N}_{\mathrm{r}}$ emissions in the form of $\mathrm{NH}_{3}$ or $\mathrm{NO}_{\mathrm{x}}$ will continue to result in an increased supply of aerosols in the atmosphere for a long time [e.g. [11]]. Secondly, the atmospheric cycle of $\mathrm{N}$ in aerosols might be relatively fast, but the $\mathrm{N}_{\mathrm{r}}$ reservoirs created in other parts of the biosphere have a much longer turnover time and so a longer potential effect on GHG emissions (e.g. nitrogen accumulation in soils and respective changes in soil C:N ratios may be effective for decades) [18]. Thirdly, $\mathrm{N}_{\mathrm{r}}$ affects the GHG concentrations in many ways as we will see from the next section and therefore, better nitrogen management, largely through improved agricultural management, will have many advantages for GHG management $[17,20]$

\section{Direct and indirect links between nitrogen and climate}

At different points of the cascade one nitrogen molecule can have a direct or indirect effect on GHG sources and sinks and on climate (Figure 2). Here we list the most important of these links and provide a preliminary quantification. More scientific background on these links is provided in $\left[17,40^{\bullet \bullet}\right]$ and is applied for Europe in [35 $5^{\bullet \bullet}$. 


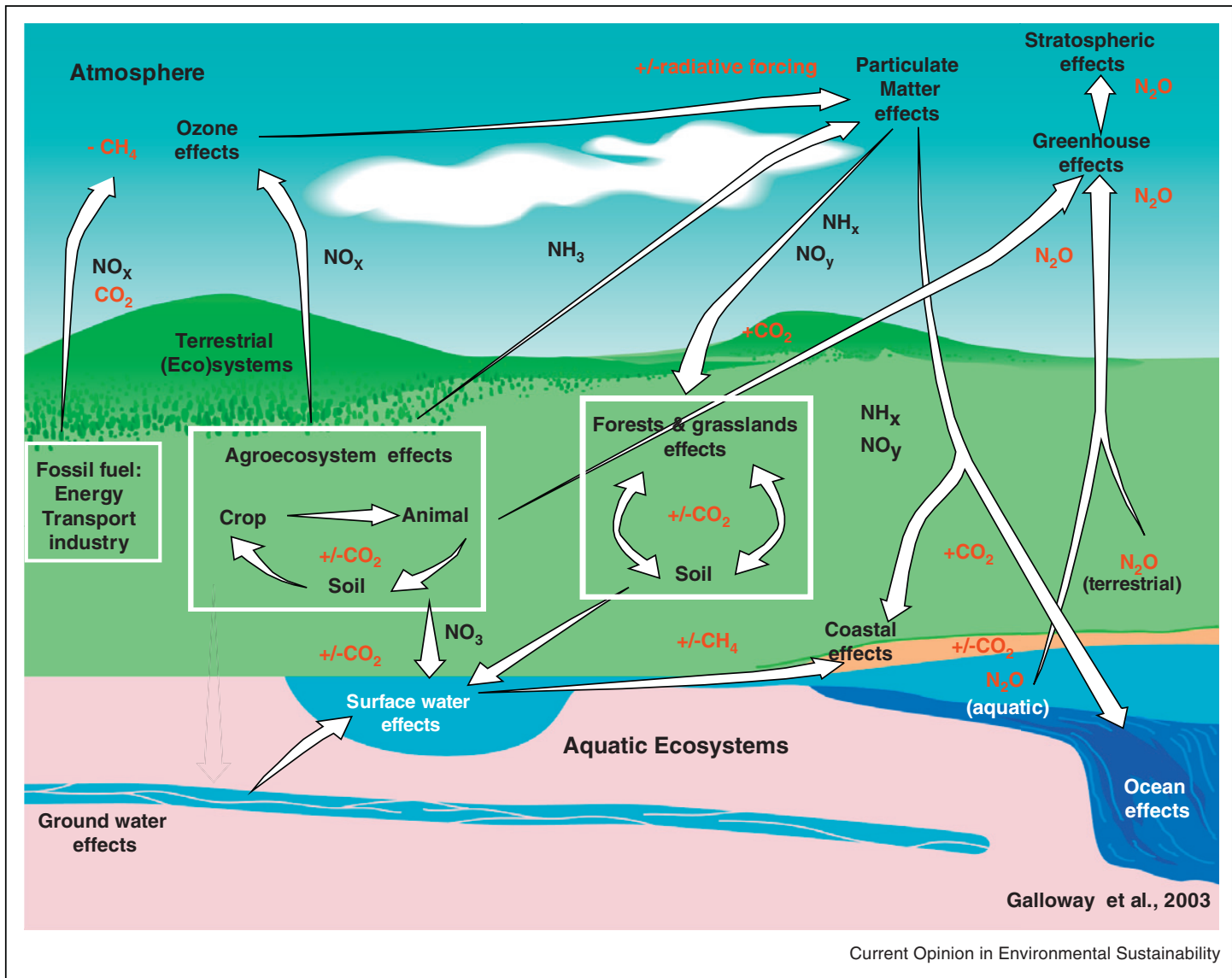

Major nitrogen and climate coupling (modified from [13*0]) visualized by the flows in the $\mathrm{N}$-cycle and the greenhouse gas and radiative forcing links (in red).

The most important direct links between $\mathrm{N}_{\mathrm{r}}$ and climate include:

a. $\mathrm{N}_{2} \mathrm{O}$ formation during industrial processes (e.g. fertilizer production), combustion, or microbial conversion of substrate containing nitrogen - notably after fertilizer and manure application to soils. $\mathrm{N}_{2} \mathrm{O}$ is a strong greenhouse gas [e.g. [2. $\left.3^{\bullet}\right]$.

b. Ground level $\mathrm{O}_{3}$ formation from $\mathrm{NO}_{\mathrm{x}} . \mathrm{O}_{3}$ is the third most important greenhouse gas.

c. Aerosol formation affecting radiative forcing, where Ncontaining aerosols have a direct cooling effect (which is in addition to an indirect cooling effect through cloud formation).

The most important indirect links between $\mathrm{N}_{\mathrm{r}}$ and climate include:

d. Alteration of the biospheric $\mathrm{CO}_{2}$ sink due to increased supply of $\mathrm{N}_{\mathrm{r}}$. About half of the carbon that is emitted to the atmosphere is taken up by the biosphere; $\mathrm{N}_{\mathrm{r}}$ affects net $\mathrm{CO}_{2}$ uptake from the atmosphere in terrestrial systems, rivers, estuaries and the open ocean in a positive direction (by increasing productivity or reducing the rate of organic matter breakdown) and negative direction (in situations where it accelerates organic matter breakdown). $\mathrm{CO}_{2}$ uptake in the ocean causes ocean acidification, which reduces $\mathrm{CO}_{2}$ uptake.

e. Excess $\mathrm{N}_{\mathrm{r}}$ deposition either increasing or reducing ecosystem productivity and so C-sequestration. Therefore, the level of $\mathrm{N}_{\mathrm{r}}$ production and deposition is important. For example, excess $\mathrm{N}_{\mathrm{r}}$ leads to hypoxia and anoxia in the ocean as well as in surface waters [21]. Hypoxic zones are mostly formed along the coastlines and via stimulated denitrification more $\mathrm{N}_{2} \mathrm{O}$ may be produced and emitted.

f. Changes in ecosystem $\mathrm{CH}_{4}$ production and consumption. $\mathrm{N}_{\mathrm{r}}$ deposition to wetlands may fuel vascular plant production, thus increasing $\mathrm{C}$ substrate supply to the system and fuel $\mathrm{CH}_{4}$ production. It may also change overall $\mathrm{CH}_{4}$ consumption by bacteria and leading to an overall change in $\mathrm{CH}_{4}$ emissions from wetlands.

g. Changes in $\mathrm{CH}_{4}$ production and emission from ruminants. Increased $\mathrm{N}_{\mathrm{r}}$ supply can be associated 
with more digestible diets, potentially reducing $\mathrm{CH}_{4}$ emission from these animals.

h. $\mathrm{O}_{3}$ formed in the troposphere as a result of $\mathrm{NO}_{\mathrm{x}}$ and VOC emissions reduces plant productivity, and therefore reduces $\mathrm{CO}_{2}$ uptake from the atmosphere.

i. $\mathrm{O}_{3}$ effects on atmospheric $\mathrm{OH}$ radical concentrations and thus atmospheric lifetime of atmospheric $\mathrm{CH}_{4}$.

\section{Quantification of global $\mathrm{N}_{\mathrm{r}}$ effects on climate $\mathrm{N}_{2} \mathrm{O}$ (a)}

The most direct effect of $\mathrm{N}_{\mathrm{r}}$ on climate is through the formation of $\mathrm{N}_{2} \mathrm{O}$, which is responsible for $11 \%$ of the net anthropogenic radiative forcing [22]. The primary source of increasing $\mathrm{N}_{2} \mathrm{O}$ is agriculture, largely due to the production of fertilizers and the expanding use of $\mathrm{N}$ fertilizers and animal manures for maintaining highly productive crop and pasture lands (e.g. $\left[23^{\bullet}, 24-26\right]$ ). $\mathrm{N}_{2} \mathrm{O}$ emissions are strongly affected by the availability of $\mathrm{N}$ in soil, estuaries and shallow sediments $\left[23^{\circ}, 27\right]$. There is some uncertainty in the emissions of $\mathrm{N}_{2} \mathrm{O}$. In addition to top-down estimates by Crutzen et al. [25], Davidson [23 $3^{\circ}$ ] recently updated the global $\mathrm{N}_{2} \mathrm{O}$ emissions to $19.8 \mathrm{Tg} \mathrm{N}_{2} \mathrm{O}-\mathrm{N}$ per year, which is higher than the 17.7 $\mathrm{Tg} \mathrm{N}_{2} \mathrm{O}-\mathrm{N}$ in AR4 [2]. Between 1750 and 2005, the change in radiative forcing at the top of the atmosphere due to increases in global atmospheric concentrations of $\mathrm{N}_{2} \mathrm{O}$ (a) was $+0.16 \mathrm{~W} \mathrm{~m}^{-2}[22]$.

Atmospheric influence of reactive $\mathbf{N}_{\mathbf{r}}$ emissions (b, c, i) For the atmospheric influence of reactive nitrogen emissions to aerosol, $\mathrm{O}_{3}$ and $\mathrm{CH}_{4}$ forcing we use the emission based estimates by Shindell et al. [19], who calculated atmospheric composition changes, historical radiative forcing, and forcing per unit of emission due to aerosol and tropospheric ozone precursor emissions in a coupled composition-climate model. They calculated the radiative forcing (from 1750 to 2000) for $\mathrm{NH}_{3}$ to be $-0.09 \mathrm{~W} \mathrm{~m}^{-2}$ as a contribution to aerosol cooling and for $\mathrm{NO}_{\mathrm{x}}$ a net cooling comprised 0.02 via $\mathrm{O}_{3}$ and $-0.31 \mathrm{~W} \mathrm{~m}^{-2}$ via reduced lifetime of tropospheric $\mathrm{CH}_{4}$ and $\mathrm{NO}_{3}$ and $\mathrm{SO}_{4}$ aerosols effects (net $-0.29 \mathrm{~W} \mathrm{~m}^{-2}$ for $\mathrm{NO}_{\mathrm{x}}$ ).

\section{Carbon and nitrogen interactions in terrestrial systems $(d+h)$}

Of the human emission of the greenhouse gas $\mathrm{CO}_{2}, 45 \%$ remains in the atmosphere, the remaining $55 \%$ is taken up by terrestrial ecosystems $(30 \%)$ and oceans (25\%) [28]. The terrestrial sink is influenced by increased nitrogen availability [29,30]. The $\mathrm{C}$ and the $\mathrm{N}$ cycles are linked through the ecosystem $\mathrm{C}: \mathrm{N}$ ratio $[31,32]$. Increasing $\mathrm{CO}_{2}$ uptake can be due to an increase in ecosystem $\mathrm{C}: \mathrm{N}$ ratio, or due to a shift of $\mathrm{N}$ from soils (low $\mathrm{C}: \mathrm{N}$ ) to vegetation (high $\mathrm{C}: \mathrm{N}$ ) [32]. Uptake of atmospheric $\mathrm{CO}_{2}$ is, therefore, limited by nitrogen availability $\left[31,33^{\circ}\right]$. Several review papers $\left[4,34,35^{\circ}\right]$ provide ranges in $\mathrm{C}$ sequestration per $\mathrm{kg} \mathrm{N}$ addition in above-ground biomass and in soil organic matter for forests and heathlands, based on: (i) empirical relations between spatial patterns of carbon uptake and influencing environmental factors including nitrogen deposition (forests only), (ii) ${ }^{15} \mathrm{~N}$ field experiments, (iii) long-term low dose $\mathrm{N}$ fertilizer experiments and (iv) results from ecosystem models. A summary of the results is given in Figure 3. Most studies range between 35 and $65 \mathrm{~kg} \mathrm{C} / \mathrm{kg} \mathrm{N}$, except for the empirical field data, which are higher but showing a large range. Furthermore, there is great uncertainty whether ecosystems will continue to retain exogenous $\mathrm{N}$ following $\mathrm{N}$ saturation [13 ${ }^{\bullet \bullet}$. The global change in radiative forcing is estimated -0.1 to $-0.3 \mathrm{~W} \mathrm{~m}^{-2}$. This does not take the $\mathrm{CO}_{2}$ fertilization effect into account.

The acceleration of the natural $\mathrm{N}$-cycle as a consequence of global warming is another mechanism to increase $\mathrm{N}$ availability to the vegetation. This mechanism works via faster litter decomposition and associated $\mathrm{N}$ mineralization rates [36]. Global integrated responses of net land $\mathrm{C}$ exchange to variation in temperature and precipitation are significantly damped by $\mathrm{C}-\mathrm{N}$ cycle coupling [ $\left[3^{\circ}\right]$. Warming will enhance soil-nitrogen mineralization, making more nitrogen available to sustain enhanced plant growth.

Several authors have evaluated the effect of including $\mathrm{C}-\mathrm{N}$ coupling in carbon and/or climate models [36-41]. Anthropogenic $\mathrm{N}$ deposition is predicted to have increased net primary productivity due to increases in foliage area and foliage $\mathrm{N}$, contributing $0.2-$ $0.5 \mathrm{Pg} \mathrm{C} \mathrm{yr}^{-1}$ to the 1990 s global net C uptake [39*]. Simulations with coupled $\mathrm{C}-\mathrm{N}$ cycles show a strong reduction of the future $\mathrm{CO}_{2}$ fertilization effect $(-0.4$ to $-0.8 \mathrm{~W} \mathrm{~m}^{-2}$ ) in comparison to models that do not account for terrestrial $\mathrm{N}$ dynamics [ $42^{\bullet \bullet}$ ]. The temperature effect due to the GHG concentration change is not taken into account.

Biophysical vegetation changes due to enhanced $\mathrm{N}$ availability are also likely to feedback on climate. Known mechanisms are adaptations in ecosystem composition, biodiversity and stature [36], changes in vegetation albedo at the leaf level [43] and vegetation shading of snow in high latitude forests [44]. These may change the surface energy balance, particularly when there are shifts from low vegetation to shrubs or forests. In drought regions, increased vegetation stature may lead to more sensitivity to soil moisture. In terrestrial systems close to agricultural and industrial areas the $\mathrm{N}$ deposition might be so high that the biodiversity is strongly reduced and even ecosystem damage occurs $\left[10^{\bullet}, 11\right]$.

$\mathrm{NO}_{\mathrm{x}}$ in the atmosphere lead to ozone production, which is damaging to crops and forests and reduces yields when critical levels are exceeded [45,46]. Loss of forest production due to excess $\mathrm{O}_{3}$ concentrations was estimated as 


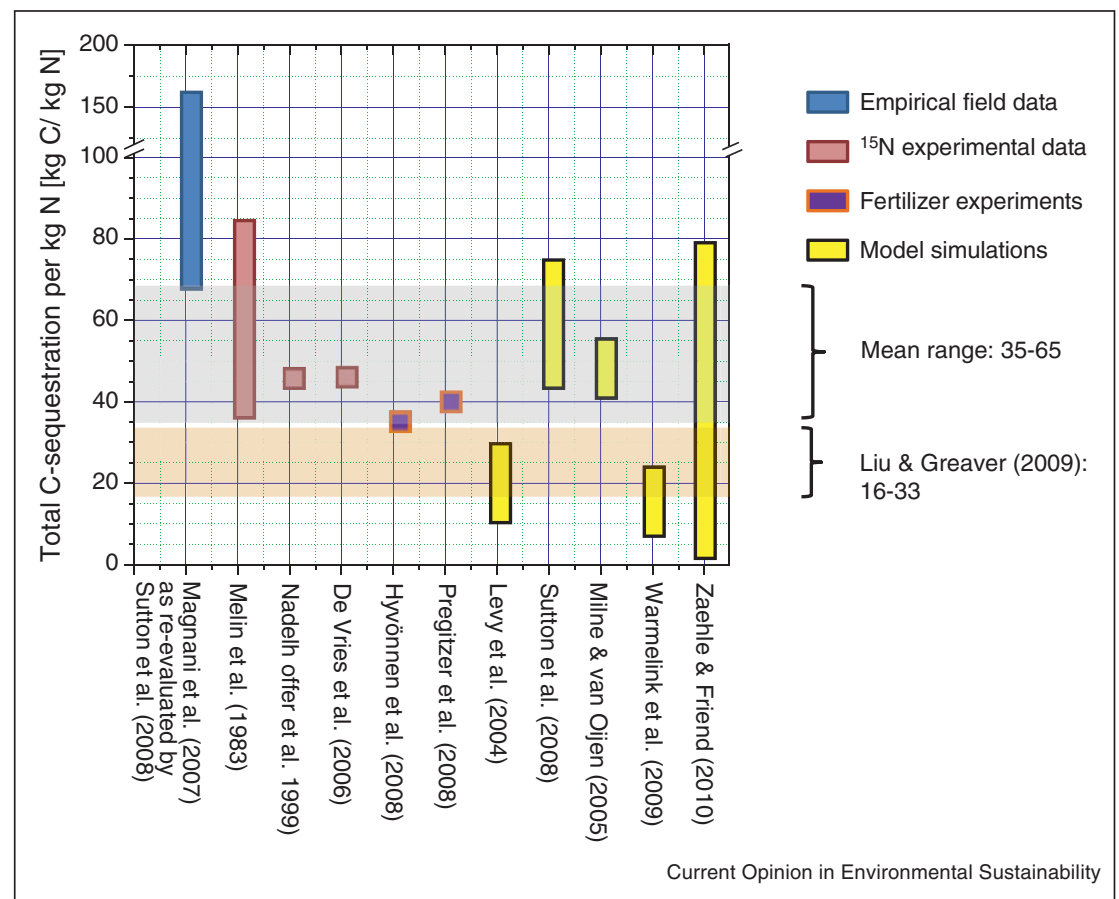

Ranges in $\mathrm{C}$ sequestration per kg N addition as number of observations in above-ground biomass and in soil organic matter for forests and heathlands, based on $\left[4,34,35^{\bullet \bullet}\right]$.

$6 \%$ of the annual yield [45] and this was assumed to be representative for the reduced $\mathrm{C}$ sequestration. Arneth et al. $\left[42^{\bullet \bullet}\right.$ ] estimate that the detrimental effects of $\mathrm{O}_{3}$ on $\mathrm{C}$ uptake could increase global radiative forcing by 0.08 $0.17 \mathrm{~W} \mathrm{~m}^{-2}$.

\section{Carbon and nitrogen interactions in oceans (e)}

The naturally occurring oxygen minimum zones (OMZ) in the open ocean and in coastal upwelling areas may increase in size under the continuous addition of $\mathrm{N}_{\mathrm{r}}$. Atmospheric deposition is a major source of nitrogen in remote areas also on the ocean [47]. Assuming today's transport pathways it is suggested that a significant increase in the magnitude or size of low oxygen areas may occur especially in the tropical and subtropical part of the ocean, which is oligotrophic today. If the areas grow in size and $\mathrm{N}$-removal processes like denitrification increase, then the ratios of $\mathrm{NO}_{3}{ }^{-}: \mathrm{PO}_{4}{ }^{3-}$ may decrease. Since these waters will be circulated and upwelled to the surface ocean the low $\mathrm{N}: \mathrm{P}$ ratio may affect the productivity of the ocean [47]. Moreover $\mathrm{N}_{2} \mathrm{O}$ is generated during denitrification and the $\mathrm{OMZ}$ may produce large quantities of $\mathrm{N}_{2} \mathrm{O}$. Increasing quantities of atmospheric anthropogenic fixed $\mathrm{N}$ entering the open ocean could account for up to about a third of the ocean's external (non-recycled) $\mathrm{N}_{\mathrm{r}}$ supply and up to $\sim 3 \%$ of the annual new marine biological production, $\sim 0.3 \mathrm{Pg}$ of $\mathrm{G}$ per year.
The change in radiative forcing is estimated between -0.1 and $-0.3 \mathrm{~W} \mathrm{~m}^{-2}$ [47].

One of the points of interest is the coupling between terrestrial/atmospheric nitrogen inputs and ocean $\mathrm{pH}$, in particular in the coastal zone. Next to stimulating primary production, the increased $\mathrm{N}_{\mathrm{r}}$ inputs will increase denitrification in the coastal zone. Besides the effect of $\mathrm{N}_{2} \mathrm{O}$, denitrification will create alkalinity, which in turn raises $\mathrm{pH}$ (thus counteracting ocean acidification) and would permit $\mathrm{CO}_{2}$ uptake from the atmosphere [e.g. [48]]. The alkalinity increases will, however, be on the coastal margins, and will be small relative to the overall acidification of the entire ocean.

\section{$\mathrm{CH}_{4}$ (f and $\mathrm{g}$ )}

There is evidence that increased $\mathrm{N}_{\mathrm{r}}$ deposition reduced methane oxidation in forest soils, and thus the sink strength of soils for atmospheric $\mathrm{CH}_{4}$ [e.g. [49]]. However, this effect of increased $\mathrm{Nr}$ availability seems only to work in soils, which are functioning as net sinks for atmospheric $\mathrm{CH}_{4}$. In ecosystems, which are net emitters of $\mathrm{CH}_{4}$ (i.e. peatlands, where this really matters), increased $\mathrm{Nr}$ availability may stimulate low affinity $\mathrm{CH}_{4}$-oxidation, which may result in decreased $\mathrm{CH}_{4}$ emissions [49]. On the other hand $\mathrm{N}_{\mathrm{r}}$ deposition to wetlands may increase plant production and, thus, substrate supply 


\begin{tabular}{|c|c|c|}
\hline \multicolumn{3}{|c|}{ The best estimate influence of nitrogen on the radiative forcing at the global scale $\left(\mathrm{W} \mathrm{m}^{-2}\right)$} \\
\hline Process & Forcing $\left(\mathrm{W} \mathrm{m}^{-2}\right)$ & Remark \\
\hline $\mathrm{N}_{2} \mathrm{O}$ emission & 0.16 & [2] \\
\hline $\mathrm{NO}_{x}$ emission atmosphere & -0.09 & [19] \\
\hline $\mathrm{NH}_{3}$ emission atmosphere & -0.29 & [19] \\
\hline \multirow[t]{3}{*}{$\mathrm{N}$ and $\mathrm{C}$ in terrestrial systems and oceans } & -0.2 & Terrestrial systems $\left[39^{\bullet \bullet}, 42^{\bullet \bullet}\right]$ \\
\hline & -0.2 & Oceans [47] \\
\hline & 0.25 & Mineralization [42*•] \\
\hline $\mathrm{O}_{3}$ phytotoxicity & 0.13 & {$\left[42^{\bullet \bullet}\right]$} \\
\hline $\mathrm{CH}_{4}$ & 0 & $\begin{array}{l}\text { Negligible. Effect on the atmospheric lifetime } \\
\text { is included in } \mathrm{NO}_{\mathrm{x}} \text { emissions }\end{array}$ \\
\hline Total & -0.24 & \\
\hline
\end{tabular}

for methanogenic bacteria, thereby increasing $\mathrm{CH}_{4}$ production and emission. On the basis of a detailed literature review Liu and Greaver [34] calculated an emission factor of $0.008 \pm 0.004 \mathrm{~kg} \mathrm{CH}_{4}-\mathrm{C} / \mathrm{kg} \mathrm{N}$, which is an order of magnitude smaller than the emission factors in Figure 3 and can be neglected.

We do not have estimates of changes in $\mathrm{CH}_{4}$ production and emission from ruminants as the result of more feed through more fertilizer $\mathrm{N}$ availability.

Table 1 summarizes the overall effect of nitrogen on the radiative forcing based on the estimations given above. We estimate an overall small net effect of $-0.24 \mathrm{~W} \mathrm{~m}^{-2}$, with a range of +0.2 to $-0.5 \mathrm{~W} \mathrm{~m}^{-2}$, based on the uncer-

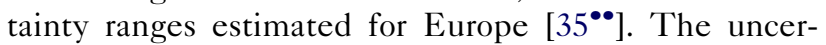
tainty in the different components is very high, especially in the atmospheric components due to the short lifetime and in the deposition effect due to the uncertainty in deposition estimates and the nutrient cycling in different systems [35 ${ }^{\bullet \bullet}$. Furthermore, most of the data are obtained from the developed parts of the world and data from developing areas are scarce.

There are many more (in)direct interlinkages, which are unquantified, small or negligible, including $\mathrm{NH}_{3}$ as a greenhouse gas; industrial formation and release of nitrogen trifluoride $\left(\mathrm{NF}_{3}\right)$, which is a very strong greenhouse gas; the role of organic $\mathrm{N}$ in the $\mathrm{N}$-cycle and its relation to the carbon cycle; reduction in soil microbes, $\mathrm{CO}_{2}$ and water uptake in areas where excess $\mathrm{N}$ deposition leads to nutrient imbalances in these ecosystems; manure storage processing producing biogas and $\mathrm{CH}_{4}$ leakages resulting from these facilities; interaction between $\mathrm{N}$-fertilizer, agricultural productivity and land use change; the $\mathrm{NH}_{3}$-based chemical industry affecting climate during the processes and from the wastes; etc. The overall impact of these linkages is unknown.

IPCG estimated the current net radiative forcing to be about $1.5 \mathrm{~W} \mathrm{~m}^{-2}$ and $\mathrm{N}$ has already been taken into account for $\mathrm{N}_{2} \mathrm{O}$ and aerosols [2]. Our estimate of $0.24 \mathrm{~W} \mathrm{~m}^{-2}$ is significant, but due to the high uncertainty and regional variability it needs to be better investigated. It shows, however, that since there is a balance between positive and negative influences of different sources on different impacts on the N-cycle, it is important to focus policies both from the environmental side as well as from the climate side in such a way that the maximum positive results are obtained.

\section{Conclusions and policy implications}

Initial quantifications of the effect of $\mathrm{N}_{\mathrm{r}}$ on climate show that there are many positive and negative influences on the GHG balance and the radiative forcing, which compensate each other leading to a small net cooling effect of $-0.24 \mathrm{~W} \mathrm{~m}^{-2}$, with a range of +0.2 to $-0.5 \mathrm{~W} \mathrm{~m}^{-2}$. The uncertainty in the individual processes is very large and given this uncertainty it is safe to say that there is a balance between cooling and warming effect of $\mathrm{N}$ which is slightly more on the cooling side, especially in the Northern Hemisphere. Ammonia emissions contribute most to the cooling effect mainly through the aerosol formation and to the $\mathrm{N}$-deposition, which stimulates $\mathrm{C}$ sequestration. $\mathrm{NO}_{\mathrm{x}}$ has more interactions and lead to a small net cooling effect. The warming effect of $\mathrm{N}_{r}$ is mainly through $\mathrm{N}_{2} \mathrm{O}$ emissions. For the long-term, if emission scenarios to reduce $\mathrm{N}_{\mathrm{r}}$ would be successful the effect could be significant. However, the radiative forcing of $\mathrm{N}_{\mathrm{r}}$ depends on the location and source type of the $\mathrm{N}_{\mathrm{r}}$ losses and, thus, a simple upscaling approach of effects of reductions of $N_{r}$ on global radiative balance remain difficult.

The effects of increased $\mathrm{N}_{\mathrm{r}}$ in the environment have led to policies limiting emissions of $\mathrm{N}_{\mathrm{r}}$ to the air and losses to soil and waters. Current policies on reducing $\mathrm{N}_{\mathrm{r}}$ emissions mainly concentrate on $\mathrm{NO}_{\mathrm{x}}$ emissions to the atmosphere. Policies on agricultural losses of $\mathrm{N}_{\mathrm{r}}$ are necessary to reduce the warming impacts mainly through $\mathrm{N}_{2} \mathrm{O}$ and to reduce the other impacts on human health and the environment. However, N management options need to be assessed to make sure that they lead to a net benefit for climate and at the same time to improved environmental quality and ecosystem services. The effects of increasing concentrations of GHGs have led to policies reducing its 
emissions. The drivers of nitrogen and climate are essentially the same and there is merit in finding the synergies between mitigation and adaptation policies. These are important reasons why the $\mathrm{N}$ cycle should be taken into account in discussions on climate and to take advantage of positive synergetic effects to address global change issues. This, however, requires an integral and multidisciplinary approach including: multi-source/actor, multi-pollutant, multi-problem, multi-benefits, multi-receptor, multi-effect, multi-scales, etc.

\section{Acknowledgements}

This paper is a contribution to the International Nitrogen Initiative (www.initrogen.org), The International Geosphere-Biosphere Programme, IGBP, and the European projects NitroEurope IP (European Commission), Nitrogen in Europe (NinE, European Science Foundation) and COST Action 729. We greatly appreciate the contributions of Mark Sutton, Oene Oenema, Maren Voss, Wim de Vries and 80 others who contributed to the draft report on Nitrogen and Climate.

\section{References and recommended reading}

Papers of particular interest published within the period of review have been highlighted as:

- of special interest

$\bullet$ of outstanding interest

1. Reid WV, Mooney HA, Cropper A, Capistrano D, Carpenter SR, Chopra K, Dasgupta P, Dietz T, Kumar Duraiappah A, Hassan R et al: Millennium Ecosystem Assessment. Ecosystems and Human Well-being: Synthesis. Washington, DC: Island Press; 2005.

2. Parry ML, Canziani OF, Palutikof JP, van der Linden PJ, Hanson CE (Eds): IPCC: Climate Change 2007: Impacts, Adaptation and Vulnerability. Contribution of Working Group II to the Fourth Assessment Report of the Intergovernmental Panel on Climate Change. Cambridge, UK: Cambridge University Press; 2007. 976.

3. Corcoran E, Nellemann C, Baker E, Bos R, Osborn D, Savelli H (Eds): Sick Water? The Central Role of Waste-water Management in Sustainable Development. A Rapid Response Assessment, United Nations Environment Programme, UN-HABITAT, GRIDArendal. 2010978-82-7701-075-5 www.grida.no.

4. De Vries W, Solberg S, Dobbertin M, Sterba H, Laubhann D, van Oijen M, Evans C, Gundersen P, Kros J, Wamelink GWW et al.: The impact of nitrogen deposition on carbon sequestration by European forests and heathlands. Forest Ecol Manage 2009, 258:1814-1823.

5. Rockström J, Will Steffen, Noone K, Persson A, Chapin SF

- Lambin EF, Lenton TM: A safe operating space for humanity Nature 2009, 461:472-475.

New approach is proposed for defining preconditions for human development Crossing certain biophysical thresholds could have disastrous consequences for humanity. Three of nine interlinked planetary boundaries have already been overstepped, one of them is nitrogen.

6. Shindell DT, Levy H II, Schwarzkopf MD, Horowitz LW,

- $\quad$ Lamarque J-F, Faluvegi G: Multimodel projections of climate change from short-lived emissions due to human activities. $J$ Geophys Res 2008, 113:D11109 doi: 10.1029/2007JD009152.

Three climate models were used to study the climate impact of the future evolution of short-lived radiatively active species (ozone and aerosols). Since short-lived species can significantly influence climate, regional air quality emission control strategies for short-lived pollutants may substantially impact climate over large (e.g. hemispheric) scales.

7. Levy H II, Schwarzkopf MD, Horowitz L, Ramaswamy V, Findell $\mathrm{KL}$ : Strong sensitivity of late 21 st century climate to projected changes in short-lived air pollutants. J Geophys Res 2008, 113:D06102 doi: 10.1029/2007JD009176.

8. Arneth A, Unger N, Kulmala M, Andreae MO: Clean the air, heat the planet? Science $2009,326: 672$.
9. Ramanathan $\mathrm{V}$, Feng $\mathrm{Y}$ : On avoiding dangerous anthropogenic interference with the climate system: formidable challenges ahead. Proc Natl Acad Sci U S A 2008, 105:14245-14250.

10. Galloway JN, Townsend AR, Erisman JW, Bekunda M, Cai Z,

- Freney JR, Martinelli LA, Seitzinger SP, Sutton MA: Transformation of the nitrogen cycle: recent trends, questions, and potential solutions. Science 2008, 320:889-892. Humans continue to transform the global nitrogen cycle at a record pace, reflecting an increased combustion of fossil fuels, growing demand for nitrogen in agriculture and industry, and pervasive inefficiencies in its use. Optimizing the need for a key human resource while minimizing its negative consequences requires an integrated interdisciplinary approach and the development of strategies to decrease nitrogen-containing waste.

11. Erisman JWMA, Sutton JN, Galloway Z, Klimont W: Winiwater: how a century of ammonia synthesis changed the world. Nat Geosci 2008, 1:636-639.

12. Mosier AR, Seyers JK, Freney JR: Nitrogen fertilizer; an essential component of increased food, feed, and fiber production. In Agriculture and the Nitrogen Cycle; Assessing the Impacts of Fertilizer Use on Food Production and the Environment. Edited by Mosier AR, Seyers JK, Freney JR. Washington, DC: Scientific Committee on Problems of the Environment (SCOPE). Island Press; 2004:3-18. (Chapter 1).

13. Galloway JN, Aber JD, Erisman JW, Seitzinger SP, Howarth RW, - Cowling EB, Cosby BJ: The nitrogen cascade. BioScience 2003, 53:.

Circulation of anthropogenic $\mathrm{N}_{\mathrm{r}}$ in Earth's atmosphere, hydrosphere, and biosphere has a wide variety of consequences, which are magnified with time as $\mathrm{N}_{\mathrm{r}}$ moves along its biogeochemical pathway. The same atom of $\mathrm{N}_{\mathrm{r}}$ can cause multiple effects in the atmosphere, in terrestrial ecosystems, in freshwater and marine systems, and on human health. We call this sequence of effects the nitrogen cascade. As the cascade progresses, the origin of $\mathrm{N}_{r}$ becomes unimportant.

14. Ravishankara, Daniel JS, Portmann RW: Nitrous oxide $\left(\mathbf{N}_{2} \mathbf{O}\right)$ : the dominant ozone-depleting substance emitted in the 21st century. Science 2009, 326:123-125.

15. Gruber N, Galloway JN: An Earth-system perspective of the global nitrogen cycle. Nature 2008, 451:293-296.

16. Marland G, Boden TA, Andres RJ: Global, regional, and national $\mathrm{CO}_{2}$ emissions. Trends: A Compendium of Data on Global Change. Oak Ridge, TN, USA: Carbon Dioxide Information Analysis Center, Oak Ridge National Laboratory, United States Department of Energy; 2007.

17. Erisman JW, Gaffney O, Bondre N (Eds): Interactions of reactive nitrogen with climate change and opportunities for integrated management strategies. In International Geosphere-Biosphere Programme (IGBP), 2011; Sweden (report in preparation).

18. Mercado LM, Bellouin N: Impact of changes in diffuse radiation on the global land carbon sink. Nature 2009, 458:1014-1017.

19. Shindell DT, Faluvegi G, Koch DM, Schmidt GA, Unger N, Bauer SE: Improved attribution of climate forcing to emissions. Science 2009, 326:716-718 doi: 10.1126/science.1174760.

20. WHRC and UNEP: Reactive nitrogen in the environment: too much or too little of a good thing. In The United Nations Environment Programme. Edited by Davidson EA, Arden-Clarke C, Braun E.Paris, France: 2007 http://www.whrc.org/resources/ publications/pdf/UNEPetal.2007.pdf.

21. Diaz RJ, Rosenberg R: Spreading dead zones and consequences for marine ecosystems. Science 2008, 321:926929 doi: 10.1126/science. 1156401.

22. Solomon S, Qin D, Manning M, Chen Z, Marquis M, Averyt KB Tignor M, Miller HL (Eds): Contribution of Working Group I to the Fourth Assessment Report of the Intergovernmental Panel on Climate Change, 2007. Cambridge, United Kingdom/New York, NY, USA: Cambridge University Press; 2007:996 http:// www.ipcc.ch/publications_and_data/ar4/wg1/en/contents.html.

23. Davidson EA: The contribution of manure and fertilizer nitrogen - to atmospheric nitrous oxide since 1860. Nat Geosci 2009 2:659-662.

Atmospheric nitrous oxide concentrations have been increasing since the industrial revolution and currently account for $6 \%$ of total anthropogenic 
radiative forcing. After 1960, the rate of the increase rose, due to accelerating use of synthetic nitrogen fertilizers. Using a regression model, it is shown that $2.0 \%$ of manure nitrogen and $2.5 \%$ of fertilizer nitrogen was converted to nitrous oxide between 1860 and 2005

24. Flynn HC, Smith P: Greenhouse Gas Budgets of Crop Production - Current and Likely Future Trends. Paris, France: International Fertilizer Industry Association; $2010 \mathrm{http}: / /$ www.fertilizer.org/ifa/Home-Page/LIBRARY/Publicationdatabase.html/Greenhouse-Gas-Budgets-of-Crop-ProductionCurrent-and-Likely-Future-Trends.html.

25. Crutzen $P$, Mosier AR, Smith $K A$, Winiwater $W: \mathbf{N}_{2} \mathbf{O}$ release from agro-biofuel production negates global warming reduction by replacing fossil fuels. Atmos Chem Phys 2008, 8:389-395 www.atmos-chem-phys.net/8/389/2008/.

26. Godfray HCJ, Beddington JR, Crute IR, Haddad L, Lawrence D, Muir JF, Pretty J, Robinson S, Thomas SM, Toulmin C: Food security: the challenge of feeding 9 billion people. Science 2010, 327:812-818 doi: 10.1126/science.1185383.

27. Seitzinger SP, Harrison JA, Dumont E, Beusen AHW, Bouwman AF: Sources and delivery of carbon, nitrogen, and phosphorus to the coastal zone: an overview of Global Nutrient Export from Watersheds (NEWS) models and their application. Glob Biogeochem Cycl 2005, 19:GB4S01 doi: $10.1029 / 2005 \mathrm{~GB} 002606$.

28. Canadell JG, Le Quéré $C$, Raupach MR, Field CB, Buitenhuis ET, Ciais P, Conway TJ, Gillett NP, Houghton RA, Marland G: Contributions to accelerating atmospheric $\mathrm{CO}_{2}$ growth from economic activity, carbon intensity, and efficiency of natural sinks. Proc Natl Acad Sci U S A 20070702737104.

29. Magnani $F$, Mencuccini $M$, Borghetti $M$, Berbigier $P$, Berninger $F$, Delzon S, Grelle A, Hari P, Jarvis PG, Kolari P et al.: The human footprint in the carbon cycle of temperate and boreal forests. Nature 2007, 447: doi: 10.1038/nature05847.

30. Reay DS, Dentener F, Smith P, Grace J, Feely RA: Global nitrogen deposition and carbon sinks. Nat Geosci 2008, 1: doi: 10.1038/ ngeo230.

31. Hungate BA, Dukes JS, Shaw MR, Luo Y, Field CB: Nitrogen and climate change. Science 2003, 302:1512-1513.

32. Rastetter EB, McKane RB, Shaver GR, Melillo JM: Changes in C storage by terrestrial ecosystems: how $\mathbf{C}-\mathbf{N}$ interactions restrict responses to $\mathrm{CO}_{2}$ and temperature. Water Air Soil Pollut 1992, 64:327-344.

33. Thornton PE, Lamarque JF, Rosenbloom NA, Mahowald NM:

- Influence of carbon-nitrogen cycle coupling on land mode response to $\mathrm{CO}_{2}$ fertilization and climate variability. Glob $B G C$ Cycl 2007, 21:GB4018.

It was demonstrated that the inclusion of nutrient cycle dynamics, specifically the close coupling between carbon and nitrogen cycles, in a terrestrial biogeochemistry component of a global coupled climate system model leads to fundamentally altered behavior for several of the most critical feedback mechanisms operating between the land biosphere and the global climate system.

34. Liu L, Greaver TL: A review of nitrogen enrichment effects on three biogenic GHGs: the $\mathrm{CO}_{2}$ sink may be largely offset by stimulated $\mathrm{N}_{2} \mathrm{O}$ and $\mathrm{CH}_{4}$ emission. Ecol Lett 2009, 12:1103-1117.

35. Butterbach-Bahl K, Nemitz E, Zaehle S, Billen G, Boeckx P,

- Erisman JW, Garnier J, Upstill-Goddard R, Kreuzer M, Oenema O et al.: Nitrogen as a threat to the European greenhouse balance. In The European Nitrogen Assessment. Edited by Sutton MA, Howard CM, Erisman JW.et al:: Cambridge University Press; 2011.

The main warming effects of European anthropogenic $\mathrm{N}_{\mathrm{r}}$ emissions are estimated to be from $\mathrm{N}_{2} \mathrm{O}\left(17(15-19) \mathrm{mW} / \mathrm{m}^{2}\right)$ and from the reduction in the biospheric $\mathrm{CO}_{2}$ sink by tropospheric $\mathrm{O}_{3}\left(4.4(2.3-6.6) \mathrm{mW} / \mathrm{m}^{2}\right)$. The main cooling effects are estimated to be from increasing the biospheric $\mathrm{CO}_{2}$ sink by atmospheric $\mathrm{N}_{\mathrm{r}}$ deposition at $-19(-30$ to -8$) \mathrm{mW} / \mathrm{m}^{2}$ and by light scattering effects of $\mathrm{N}_{\mathrm{r}}$ containing aerosol ( -16.5 ( -27.5 to $-5.5) \mathrm{mW} / \mathrm{m}^{2}$, in both cases resulting from emissions of $\mathrm{NO}_{x}$ and $\mathrm{NH}_{3}$. Overall, European $\mathrm{N}_{\mathrm{r}}$ emissions are estimated to have a net cooling effect, with the uncertainty bounds ranging from a substantial cooling effect to a small warming effect $\left(-15.7(-46.7\right.$ to +15.4$\left.) \mathrm{mW} / \mathrm{m}^{2}\right)$.

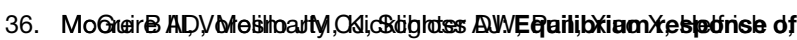
global net primary production and carbon storage to doubled atmospheric carbon dioxide: sensitivity to changes in vegetation nitrogen concentration. Glob BGC CyCl 1997 11:1730189.

37. Sokolov AP, Kicklighter DW, Melillo JM, Felzer B, Schlosser CA, Cronin TW: Consequences of considering carbon-nitrogen interactions on the feedbacks between climate and the terrestrial carbon cycle. J Clim 2008, 21:3776-3796.

38. $\mathrm{Xu}-\mathrm{Ri}$, Prentice IC: Terrestrial nitrogen cycle simulation with a dynamic global vegetation model. Glob Change Biol 2008, 14:1745-1764 doi: 10.1111/j.1365-2486.2008.01625.

39. Zaehle S, Friend AD: Carbon and nitrogen cycle dynamics in the

- O-CN land surface model. 1. Model description, site-scale evaluation, and sensitivity to parameter estimates. Glob Biogeochem Cycl 2010, 24:GB1005 doi: 10.1029/2009GB003521. The effects of nitrogen $(\mathrm{N})$ constraints on future terrestrial carbon (C) dynamics were investigated using a O-CN land surface model. $\mathrm{N}$ dynamics reduce terrestrial $\mathrm{C}$ storage due to $\mathrm{CO}_{2}$ fertilization over the period $1860-2100$ by $50 \%$ (342 Pg C) mainly in mid-high latitude ecosystems, compared to a simulation not accounting for $\mathrm{N}$ dynamics.

40. Zaehle S, Friend AD, Dentener F, Friedlingstein P, Peylin P,

-. Schulz M: Carbon and nitrogen cycle dynamics in the O-CN land surface model. 2 . Role of the nitrogen cycle in the historical terrestrial carbon balance. Glob Biogeochem $\mathrm{Cycl}$ 2010, 24:GB1006 doi: 10.1029/2009GB003522.

Global-scale results of the new O-CN terrestrial biosphere model coupling the carbon $(\mathrm{C})$ and nitrogen $(\mathrm{N})$ cycles show that the model produces realistic estimates of present-day $\mathrm{C}$ and $\mathrm{N}$ stocks and fluxes, despite some regional biases. Anthropogenic $\mathrm{N}$ deposition was predicted to have increased net primary productivity due to increases in foliage area and foliage $\mathrm{N}$, contributing $0.2-0.5 \mathrm{Pg} \mathrm{C} \mathrm{yr}^{-1}$ to the $1990 \mathrm{~s}$ global net $\mathrm{C}$ uptake.

41. Thornton P, Doney SC, Lindsay K, Moore JK, Mahowald NM Randerson JT, Fung IY, Lamarque J-F, Feddema JJ, Lee Y-H: Carbon-nitrogen interactions regulate climate-carbon cycle feedbacks: results from an atmosphere-ocean general circulation model. Biogeosciences 2009, 6:2099-2120 doi: $10.5194 / \mathrm{bg}-6-2099-2009$.

42. Arneth A, Harrison SP, Zaehle S, Tsigaridis K, Menon S,

- Bartlein PJ, Feichter J, Korhola A, Kulmala M, O'Donnell D: Terrestrial biogeochemical feedbacks in the climate system. Nat Rep Clim Change 2010, 3:525.

Total positive radiative forcings resulting from feedbacks between the terrestrial biosphere and the atmosphere are estimated to reach up to 0.9 or $1.5 \mathrm{~W} \mathrm{~m} \mathrm{~m}^{-2} \mathrm{~K}^{-1}$ towards the end of the twenty-first century, depending on the extent to which interactions with the nitrogen cycle stimulate or limit carbon sequestration. The overall magnitude of the biogeochemical feedbacks could potentially be similar to that of feedbacks in the physical climate system, but there are large uncertainties in the magnitude of individual estimates and in accounting for synergies between these effects.

43. Ollinger SV, Richardson AD, Martin ME, Hollinger DY, Frolking SE, Reich PB, Plourde LC, Katul GG, Munger JW, Oren R et al.: Canopy nitrogen, carbon assimilation, and albedo in temperate and boreal forests: functional relations and potential climate feedbacks. Proc Natl Acad Sci U S A 2008, 49:19336-19341.

44. Betts AK, Viterbo P, Beljaars A, van den Hurk BJJM: Impact of BOREAS on the ECMWF forecast model. J Geophys Res 2000 , 106:33593-33604.

45. Skarby L, Ottosson S, Karlsson PE, Wallin G, Sellden G, Medin EL, Pleijel H: Growth of Norway spruce (Picea abies) in relation to different ozone exposure indices: a synthesis. Atmos Environ 1352-23102004, 38:2225-2236 doi: 10.1016/ j.atmosenv.2003.10.059 New methods of risk assessment for ozone impacts on vegetation.

46. Van Dingenen R, Dentener FJ, Raes F, Krol MC, Emberson L, Cofal J: The global impact of ozone on agricultural crop yields under current and future air quality legislation. Atmos Environ 2009, 43:604-618.

47. Duce RA, Roche JL, Altieri K, Arrigo K, Baker A, Capone D, Cornell S, Dentener F, Galloway J, Ganeshram R et al.: Impacts of 
atmospheric anthropogenic nitrogen on the open ocean. Science 2008, 320:893-897 doi: 10.1126/science.1150369.

48. Thomas H, Schiettecatte L-S, Suykens K, Koné YJM,

Shadwick EH, Prowe F, Bozec Y, de Baar HJW, Borges AV: Enhanced ocean carbon storage from anaerobic alkalinity generation in coastal sediments. Biogeosciences 2009 , 6:267-274 doi: 10.1029/2007JD009152.
49. Bodelier PLE, Laanbroek $\mathrm{HJ}$ : Nitrogen as a regulatory factor in methane oxidation in soils and sediments. FEMS Microbiol Ecol 2004, 47:265-277.

50. Schlesinger $\mathrm{WH}$ : On the fate of anthropogenic nitrogen. Proc Natl Acad Sci U S A 2009, 104:203-208. 